\title{
Initiation of embryogenic callus from mature zygotic embryos in Japanese larch (Larix kaempferi)
}

\author{
Yong-Wook Kim
}

Received: 11 September 2015 / Revised: 23 September 2015 / Accepted: 23 September 2015

(C) Korean Society for Plant Biotechnology

\begin{abstract}
Embryogenic callus (EC) was created from mature embryos of Larix kaempferi. With the mature embryos, keeping the culture in dark conditions throughout the experiment (38.2\%) seemed to give better results than exposing them to $16 \mathrm{~h}$ light $\left(25 \mathrm{\mu Em}^{-2} \mathrm{~s}^{-1}\right)$ for the first week (21.9\%). EC was obtained most frequently from Quoirin and Lepoivre (LP) mediums with $1.0 \mathrm{mg} / \mathrm{L}$ 4-amino-3,5,6trichloropicolinic acid (Picloram), plus $1.0 \mathrm{mg} / \mathrm{L}$ benzyladenine (BA) $(62.8 \%$ ) or Litvay's medium (LM) containing $1.0 \mathrm{mg} / \mathrm{L}$ p-chlorophenoxyacetic acid (pCPA) plus $1.0 \mathrm{mg} / \mathrm{L}$ BA $(62.8 \%)$ treatment. In both cases, best results were obtained when zygotic embryos were cultured in darkness. As for the effective sucrose concentration on initiation of EC, $29.2 \mathrm{mM}$ sucrose $(38.6 \%)$ gave the best results.
\end{abstract}

Keywords Embryogenic callus, Japanese larch, Somatic embryos, Zygotic mature embryos

\section{Introduction}

The genus Larix is widely distributed in temperate zone of the world. Larch has been considered as one of the candidates for reforestation and genetic improvement because of its wood quality, fast growth, and wide ecological adaptability (Bailian and Wyckoff 1994; Gowere and Richards, 1990). In addition, larch has wood and fiber characteristics suitable for kraft pulping, with young trees exhibiting pulp strength and yields comparable to mature jack pine and other conifers (Einspahr et al. 1983; Hatton 1986). However, the use of this species for reforestation has been hindered due to a low seed set and poor germination (Lelu et al. 1994a). A solution for this problem

Y. W. Kim $(\square)$

Department of Forest Genetics, Korea Forest Research Institute, Suwon, 441-847, Korea

e-mail: bravekim@korea.kr may be employing somatic embryogenesis culture system to produce unlimited number of propagules having identical genetic make-up originated from a single seed (Attree and Fowke 1991). This culture technique might accelerate traditional tree improvement programs by reducing the time required to produce genetically improved forest trees. In the genus Larix, somatic embryogensis has been reported with female gametophytes of Larix decidua (von Aderkas and Bonga 1988; Nagmani and Bonga 1985), immature embryos of $L$. decidua, L. ×eurolepis, L. ×leptoeuropaea (Lelu et al. 1994a), L. ×eurolepis (Klimaszewska 1989), L. occidentalis (Thompson and von Aderkas 1992), and L. ×leptoeuropaea (Lelu et al. 1994a). In L. kaempferi, only EC induction has been reported to date with both female gametophyte and immature embryos (von Aderkas et al. 1990). However, it has not been successful to induce somatic embryos and plant regeneration from embryogenic cultures of this species. The main reason might be that $L$. kaempferi is generally regarded as more recalcitrant species to in vitro system-adventitious shoot bud induction from embryo and/or embryonic tissue (Bonga and Pond 1991; Diner et al. 1986) than any other conifer species. Therefore, there is a need to establish the optimal conditions to induce somatic embryogenesis of $L$. kaempferi. The aim of this report was to know the appropriate in vitro conditions for the initiation of EC from mature embryos of this species. This study may also offer the basic data for the further somatic embryo induction and plant regeneration form the established EC of L. kaempferi.

\section{Materials and Methods}

Plant materials

The mature embryos of L. kaempferi were harvested in October from the seed orchard at Interior Breeding Station of Korea Forest Seed and Variety Center located in Chung ju, 
Korea. The seeds were stored at $4^{\circ} \mathrm{C}$ until use. Immediately before removal of the mature embryos, the seeds were imbibed in tap water for $24 \mathrm{~h}$ at room temperature. After imbibition, sound seeds were selected. The seeds were soaked in tap water for $10 \mathrm{~min}$ with a drop of tween 20 , and then surface sterilized in $30 \%$ hydrogen peroxide solution for 30 min followed by washing one time with sterile distilled water. And the seeds were disinfected with $10 \%$ sodium hypochlorite solution for $30 \mathrm{~min}$ by shaking vigorously. After the seeds were washed once with distilled water, they were submerged in $1.0 \%(\mathrm{w} / \mathrm{v})$ mercuric chloride solution for $20 \mathrm{~min}$, and then washed four times with sterile distilled water.

EC initiation from mature embryos

After the mature embryos were extracted from the female megagametophytes, they were bisected transversally, and placed on EC medium. The ovuliferous scales were discarded, and the mature zygotic embryos were cultured on three EC initiation media such as modified LP (Quoirin and Lepoivre 1977), LM (Litvay et al. 1985), and SH (Schenk and Hildebrandt 1972). Each medium was composed of full-strength salts and vitamines supplemented with $1,000 \mathrm{mg} / \mathrm{L}$ casein hydrolysate, $3.4 \mathrm{mM}$ glutamine, $29.2 \mathrm{mM}$ sucrose, and $0.2 \%$ (v/v) gelrite (Sigma) as a gelling agent. L-Glutamine was sterilized with a disposable filter unit $(0.2 \mu \mathrm{m}$ pore size $)$ and then added to cooled medium after autoclaving. The medium was supplemented with one of the three types of auxins; 2,4-D, Picloram or pCPA, at the concentrations ranging from 1.0 to $5.0 \mathrm{mg} / \mathrm{L}$, and one cytokinin (BA) first at the concentrations of $1.0 \mathrm{mg} / \mathrm{L}$ (see Table 1 and 2). Two different culture methods were employed, the first was culturing the mature embryos in the $25 \mu \mathrm{Em}^{-2} \mathrm{~s}^{-1}$ light for one week followed by transferring to darkness for 7 weeks. The second treatment was incubating them in darkness throughout. After 4 weeks in culture, all the cultures were transferred to fresh medium. The frequency of EC was surveyed after 8 weeks in culture.

\section{Effect of sucrose concentrations on EC initiation}

The effect of various concentrations (14.6, 29.2, 58.4, 87.6, $116.8,146 \mathrm{mM}$ ) of sucrose on EC initiation was tested. Totally 60 embryos were cultured on each of the 6 different sucrose concentrations with three replicates. Ten mature embryos were placed on each petri-dish $(87 \times 15 \mathrm{~mm})$ with medium. The cultures were kept in darkness at $25 \pm 1^{\circ} \mathrm{C}$ for 8 weeks. The frequency of $\mathrm{EC}$ initiation was recorded after the initial 8 weeks of culture.
Table 1 Effect of media and plant growth regulators on embryogenic tissue initiation grown in the light from mature zygotic embryos of L. kaempferi ${ }^{\text {a }}$

\begin{tabular}{|c|c|c|c|c|c|}
\hline \multirow{2}{*}{ Medium- } & \multicolumn{4}{|c|}{ Plant growth regulators $(\mathrm{mg} / \mathrm{L})$} & \multirow{2}{*}{$\begin{array}{c}\text { ET initiation } \\
(\% \pm \text { S.E. })\end{array}$} \\
\hline & 2,4-D & Picloram $^{b}$ & $\mathrm{pCPA}^{\mathrm{c}}$ & BAP & \\
\hline \multirow[t]{9}{*}{$\mathrm{LM}^{\mathrm{e}}$} & 1.0 & & & 1.0 & $16.0 \pm 1.9 \mathrm{cdefg}^{\mathrm{d}}$ \\
\hline & 2.0 & & & 1.0 & $28.0 \pm 3.7 \mathrm{abcde}$ \\
\hline & 5.0 & & & 1.0 & $12.5 \pm 3.1 \mathrm{efg}$ \\
\hline & & 1.0 & & 1.0 & $20.9 \pm 3.3 \mathrm{bcdefg}$ \\
\hline & & 2.0 & & 1.0 & $28.0 \pm 3.8 \mathrm{abcde}$ \\
\hline & & 5.0 & & 1.0 & $12.0 \pm 2.2 \mathrm{fg}$ \\
\hline & & & 1.0 & 1.0 & $18.0 \pm 3.9 \mathrm{bcdefg}$ \\
\hline & & & 2.0 & 1.0 & $20.0 \pm 3.9 \mathrm{bcdefg}$ \\
\hline & & & 5.0 & 1.0 & $8.0 \pm 1.0 \mathrm{~g}$ \\
\hline \multirow[t]{9}{*}{$\overline{L P^{f}}$} & 1.0 & & & 1.0 & $10.1 \pm 0.1 \mathrm{fg}$ \\
\hline & 2.0 & & & 1.0 & $17.0 \pm 1.7 \mathrm{bcdefg}$ \\
\hline & 5.0 & & & 1.0 & $8.5 \pm 1.9 \mathrm{~g}$ \\
\hline & & 1.0 & & 1.0 & $24.7 \pm 2.3 \mathrm{bcdef}$ \\
\hline & & 2.0 & & 1.0 & $24.4 \pm 4.3 \mathrm{bcdef}$ \\
\hline & & 5.0 & & 1.0 & $15.4 \pm 2.1 \mathrm{defg}$ \\
\hline & & & 1.0 & 1.0 & $13.5 \pm 2.8 \mathrm{efg}$ \\
\hline & & & 2.0 & 1.0 & $12.7 \pm 3.6 \mathrm{efg}$ \\
\hline & & & 5.0 & 1.0 & $17.2 \pm 3.0 \mathrm{bcdefg}$ \\
\hline \multirow[t]{9}{*}{$\mathrm{SH}^{\mathrm{g}}$} & 1.0 & & & 1.0 & $32.5 \pm 2.7 \mathrm{ab}$ \\
\hline & 2.0 & & & 1.0 & $16.0 \pm 8.0 \mathrm{cdefg}$ \\
\hline & 5.0 & & & 1.0 & $17.8 \pm 2.9 \mathrm{bcdefg}$ \\
\hline & & 1.0 & & 1.0 & $24.8 \pm 3.8 \mathrm{bcdef}$ \\
\hline & & 2.0 & & 1.0 & $31.4 \pm 2.9 \mathrm{abc}$ \\
\hline & & 5.0 & & 1.0 & $20.6 \pm 2.6 \mathrm{bcdefg}$ \\
\hline & & & 1.0 & 1.0 & $29.6 \pm 10.4 \mathrm{abcd}$ \\
\hline & & & 2.0 & 1.0 & $41.7 \pm 13.0 \mathrm{a}$ \\
\hline & & & 5.0 & 1.0 & $11.3 \pm 4.5 \mathrm{fg}$ \\
\hline
\end{tabular}

${ }^{\mathrm{a}}$ The mature embryos were cultured in the light $\left(25 \mu \mathrm{Em}^{-2} \mathrm{~s}^{-1}\right)$ for one week followed by darkness for 7 weeks.

${ }^{\mathrm{b}}$ 4-amino-3,5,6-trichloropicolinic acid

cpara-chlorophenoxyacetic acid

${ }^{\mathrm{d}}$ Means with the same letter are not significantly different as determined by analysis of variance with Duncan's mutiple range test. $\mathrm{Pr}>\mathrm{F}: 0.0001, \mathrm{~F}$ value: 3.32

${ }^{\mathrm{e}}$ Litvay et al. (1985)

${ }^{\mathrm{f}}$ Quoirin and Lepoivre (1977)

${ }^{\mathrm{g}}$ Schenk and Hilderbrandt (1972)

Observations and photographs of scanning electron microscopy

For the investigation of somatic embryogenesis by scanning electron microscope, several pieces of embryogenic or non-embryogenic callus were collected after 8 weeks in 
culture. No dehydration or fixation treatment was done on the sample. Observations and photographs were made on a ABT-55 scanning electron microscope (Toshiba, Japan).

Statistical analysis

Analyses of variance were performed for frequency of embryogenic tissue initiation and somatic embryo maturation. Statistically significant mean differences were determined with Duncan's mutiple range test.

Table 2 Effect of media and plant growth regulators on embryogenic tissue initiation grown in the dark from mature zygotic embryos of L. kaempferi ${ }^{\text {a }}$

\begin{tabular}{|c|c|c|c|c|c|}
\hline \multirow{2}{*}{ Medium } & \multicolumn{4}{|c|}{ Plant growth regulators (mg/L) } & \multirow{2}{*}{$\begin{array}{c}\text { ET initiation }{ }^{b} \\
(\% \pm \text { S.E. })\end{array}$} \\
\hline & $2,4-\mathrm{D}$ & Picloram & pCPA & BAP & \\
\hline \multirow[t]{9}{*}{ LM } & 1.0 & & & 1.0 & $51.2 \pm 8.1$ abcdef \\
\hline & 2.0 & & & 1.0 & $42.0 \pm 2.0 \mathrm{bcdefgh}$ \\
\hline & 5.0 & & & 1.0 & $30.0 \pm 5.8 \mathrm{ghijklm}$ \\
\hline & & 1.0 & & 1.0 & $56.4 \pm 4.9 \mathrm{abcd}$ \\
\hline & & 2.0 & & 1.0 & $56.0 \pm 9.5 \mathrm{abcd}$ \\
\hline & & 5.0 & & 1.0 & $18.8 \pm 2.4 \mathrm{ijk} \mathrm{km}$ \\
\hline & & & 1.0 & 1.0 & $62.8 \pm 5.4 \mathrm{a}$ \\
\hline & & & 2.0 & 1.0 & $41.2 \pm 7.1$ bcdefgh \\
\hline & & & 5.0 & 1.0 & $54.0 \pm 5.7 \mathrm{abcde}$ \\
\hline \multirow[t]{9}{*}{ LP } & 1.0 & & & 1.0 & $60.0 \pm 2.9 \mathrm{ab}$ \\
\hline & 2.0 & & & 1.0 & $37.8 \pm 4.5$ cdefghi \\
\hline & 5.0 & & & 1.0 & $14.0 \pm 0.71 \mathrm{~m}$ \\
\hline & & 1.0 & & 1.0 & $62.8 \pm 10.2 \mathrm{a}$ \\
\hline & & 2.0 & & 1.0 & $32.1 \pm 5.0$ fghijkl \\
\hline & & 5.0 & & 1.0 & $16.0 \pm 4.6 \mathrm{klm}$ \\
\hline & & & 1.0 & 1.0 & $14.0 \pm 3.31 \mathrm{~m}$ \\
\hline & & & 2.0 & 1.0 & $16.0 \pm 4.6 \mathrm{klm}$ \\
\hline & & & 5.0 & 1.0 & $10.4 \pm 3.2 \mathrm{~m}$ \\
\hline \multirow[t]{9}{*}{ SH } & 1.0 & & & 1.0 & $44.7 \pm 7.2 \mathrm{abcdefgh}$ \\
\hline & 2.0 & & & 1.0 & $35.4 \pm 4.1$ efghijk \\
\hline & 5.0 & & & 1.0 & $28.0 \pm 8.5 \mathrm{hijklm}$ \\
\hline & & 1.0 & & 1.0 & $55.0 \pm 9.8 \mathrm{abcdefg}$ \\
\hline & & 2.0 & & 1.0 & 4.7 \pm 2.2 abcdefgh \\
\hline & & 5.0 & & 1.0 & $17.4 \pm 2.0 \mathrm{jklm}$ \\
\hline & & & 1.0 & 1.0 & $57.1 \pm 9.2 \mathrm{abc}$ \\
\hline & & & 2.0 & 1.0 & $42.0 \pm 9.9$ bcdefgh \\
\hline & & & 5.0 & 1.0 & $36.2 \pm 1.9 \mathrm{defghij}$ \\
\hline
\end{tabular}

${ }^{a}$ The mature embryos were cultured in the dark throughout the 8 week culture.

${ }^{b}$ Means with the same letter are not significantly different as determined by analysis of variance with Duncan's mutiple range test. $\operatorname{Pr}>\mathrm{F}: 0.0001, \mathrm{~F}$ value: 7.71 .

\section{Results and discussion}

EC initiation from mature embryos

When the mature embryos were placed on EC initiation medium within 1 to 2 days in culture, the explants developed red color in the hypocotyl and radicle parts (Fig. 1a). After the 5 days, the embryos became gradually swollen, and started EC initiation from the hypocotyle zone (Fig. 1b). At this time, the induced EC showed the typical features that appeared only in EC such as white to translucent, and mucilaginous texture (Fig. 1c) as has been reported (Liao and Amerson 1995). When examined by SEM, the EC appeared to have long filamentous shape with embryonal head as well as suspensor (Fig. 2b). On the other hand, non-embryogenic callus (NEC) with isodiametric small cells could also be observed (Fig. 2a). After 7-9 days in culture, the early-staged somatic embryos having both putative embryonal head and suspensor were induced from the cultured EC. After 2 weeks, the distinctive proembryos having both embryonal head and suspensor could also be observed (Fig. 1d). The effect of the three basal media on the EC initiation from mature embryos was compared. Regardless of light conditions, the best results were obtained from LMmedium (45.8\%), followed by SH medium (39.5\%), and LP medium (29.2\%) (Table 1 and 2). Since the LM salt formulation appeared to be the most satisfactory for EC initiation, it was selected thereafter as a basal induction medium in the immature zygotic embryos. The LM medium

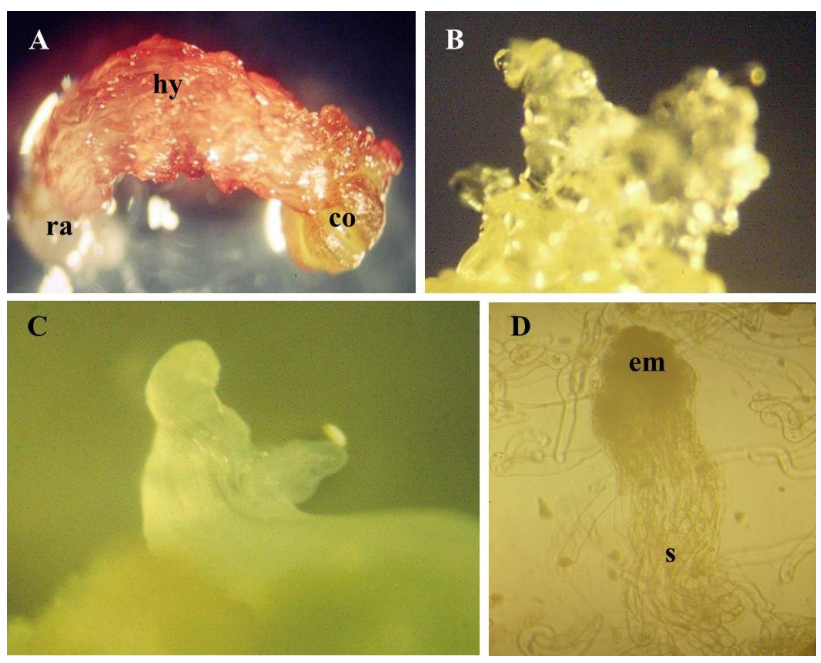

Fig. 1 The embryogenic callus (EC) initiation in L. kaempferi. (A) The mature zygotic embryos with radicle (ra), hypocotyl (hy), and cotyledon (co) after 2 days in culture. The explant showed swollen and red color pigmentation in hypocotyl or radicle parts. (B) Initiation of EC from the hypocotyl region. (C) Proliferating EC shown in Fig. 1b. (D) Formation of immature somatic embryos with embryonal head and suspensor (arrows) 
has been reported to be effective in other conifer species (von Aderkas and Bonga 1987; Beardmore and Charest 1995). Keeping the culture in the dark condition throughout the experiment (38.2\%) seemed to give better results than exposing them to $16 \mathrm{~h}$ light $\left(25 \mu \mathrm{Em}^{-2} \mathrm{~s}^{-1}\right)$ for the first one week (21.9\%) in this species. Gupta and Durzan (1989) also reported that keeping the cultures in the darkness was essential for the induction of EC from the mature embryos of Norway spruce. However, Verhagen and Wana (1989) showed that the initiated EC grow equally well under a $16 \mathrm{~h}$ light photoperiod in Norway spruce mature embryos. However, in our preliminary experiment, as soon as EC appeared, they started to lose their embryogenic phenotype (i.e. color and texture). We moved EC from dark to light condition, upon transfer, they turned to NEC having green color or isodiametric cells within one week as shown in SEM pictures. The three kinds of auxins (2,4-D, Picloram, and

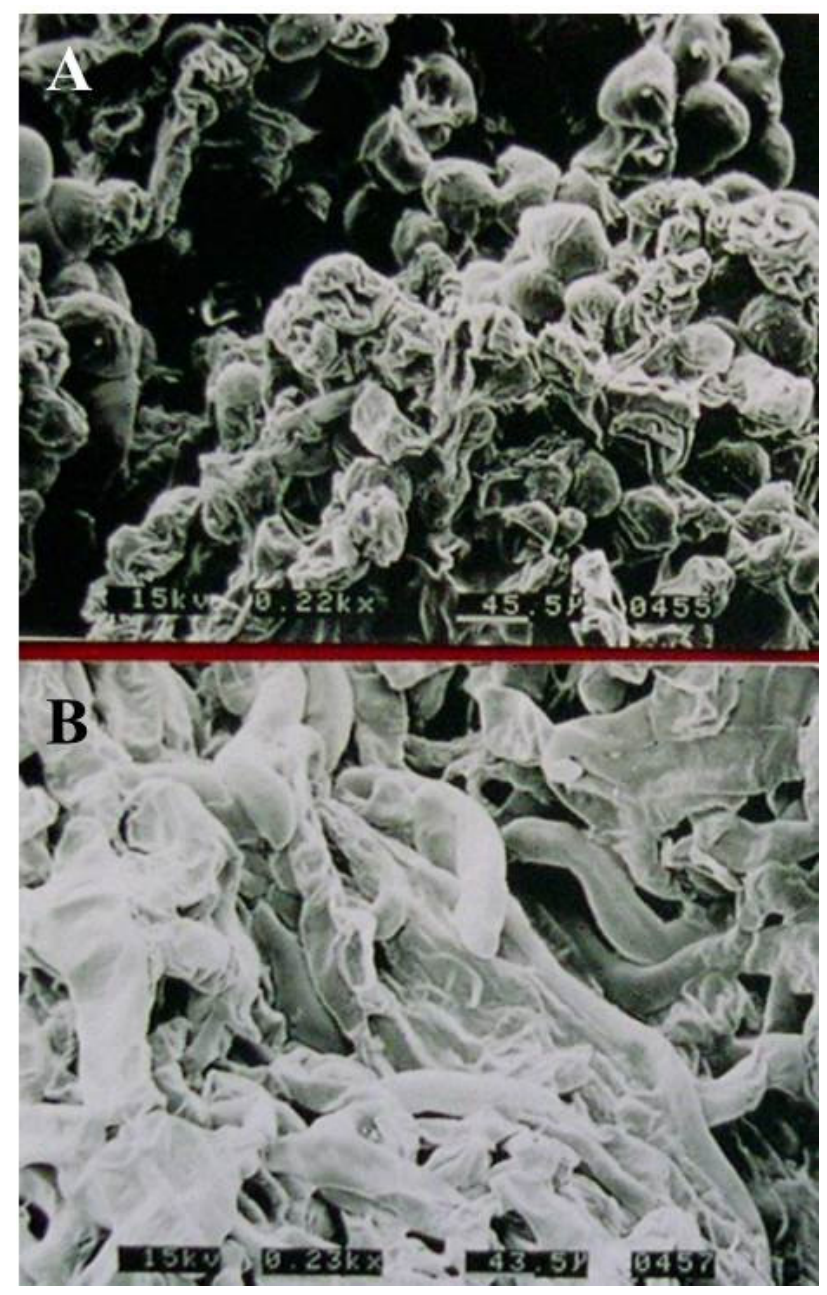

Fig. 2 Scanning electron micrographs of non-embryogenic or EC callus in L. kaempferi. (A) Non-embryogenic callus, characterized by small, compact spherical and isodiametric cells. (B) EC showed numerous elongated structures containing immature somatic embryos
pCPA) at various concentrations $(1.0 \sim 5.0 \mathrm{mg} / \mathrm{L})$ were tested for their ability to initiate $\mathrm{EC}$ when combined with a cytokinin (1.0 mg/L BA) (Table 1 and 2). The best EC forming frequency was obtained from LP medium with $1.0 \mathrm{mg} / \mathrm{L}$ Picloram plus $1.0 \mathrm{mg} / \mathrm{L} \mathrm{BA}(62.8 \%)$ or $\mathrm{LM}$ medium containing $1.0 \mathrm{mg} / \mathrm{L}$ pCPA plus $1.0 \mathrm{mg} / \mathrm{L}$ BA $(62.8 \%)$ treatment (Table 2). This result seems to be better than those reported with other larch species (Klimaszewska 1989; von Aderkas et al. 1990). The addition of Picloram (1.0 5.0 mg/L) or pCPA $(1.0 \sim 5.0 \mathrm{mg} / \mathrm{L})$ seemed to be beneficial to inducing EC from L. kaempferi mature embryos. This result appeared to be similar to that obtained with immature embryos of Picea glauca which needed $1.0 \mathrm{mg} / \mathrm{L}$ Picloram for EC initiation ( $\mathrm{Lu}$ and Thorpe 1986). However, it is unusual that the highest EC initiation frequency was obtained from Picloram or pCPA treatment considering that it is routinely supplemented with 2,4-D for primary medium (induction medium) to initiate EC from conifer embryos.

\section{Effect of sucrose concentrations on EC initiation}

As for the effective sucrose concentration on initiation of EC, $29.2 \mathrm{mM}$ sucrose (38.6\%) gave the best results (Fig. 3). Studying with the megagametophytes of $L$. decidua, von Aderkas and Bonga (1987) reported that the medium containing $87.6 \mathrm{mM}$ sucrose $(80 \%$ ) produced the best results. Although a high yield of EC could be obtained on LP medium containing $29.2 \mathrm{mM}$ sucrose, the yield decreased as the embryos became matured. In the case of mature embryos of Picea abies, von Arnold and Hakman (1986) reported that sucrose in the medium had a marked effect on the initiation of the embryogenic type callus. The results of this study as well as other previously reported suggest that the sucrose concentration in the medium plays an important role in EC

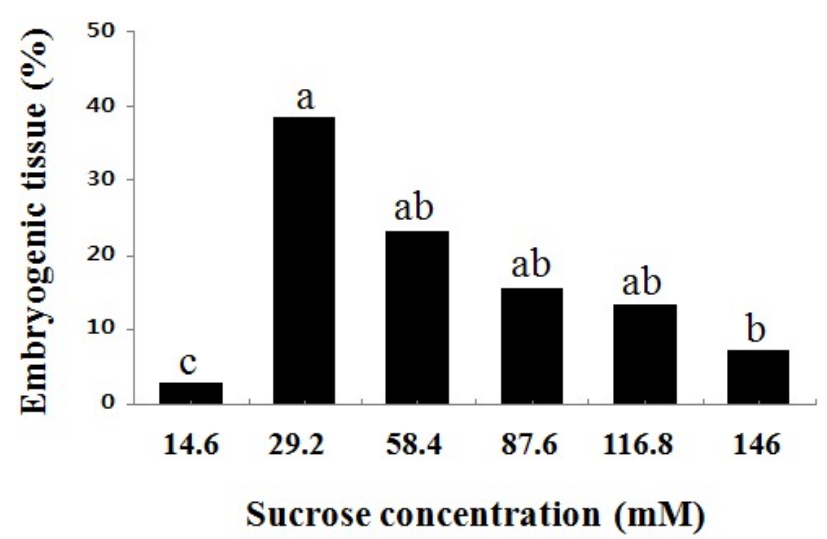

Fig. 3 Effect of sucrose concentrations on the initiation of EC from mature zygotic embryos in L. kaempferi $(\mathrm{Pr}>\mathrm{F}: 0.167, \mathrm{~F}$ value: 2.54 ) 
initiation. Therefore, varying concentrations of sucrose should be tested in culture medium depending on conifer species (Lelu et al. 1994b; Nagmani and Bonga 1985).

\section{Conclusion}

The low number of viable embryos of $L$. kaempferi resulted from severe damages by both blight and harmful insects, Dioryctria abietella, in growing seasons (early June-late July). By this reason, it was not possible to get sufficient sound seeds for experiment. Also, the seeds looking normal in appearance are frequently inviable, or empty. In this study, the majority of initiated EC failed or quickly ceased to proliferate upon subculture. In addition, even some of the surviving EC lost their capability for vigorous proliferation and died during the course of subculture. The necrosis of all EC within the first-two weeks after subculture on the fresh medium leads us for urgent necessity of developing methods to maintain the viability of EC if somatic embryogenesis is to become a useful technique in this species.

\section{References}

Attree SM, Fowke LC (1991) Conifer somatic embryogenesis. In:Bajai YPS(Ed) Biotechnology in Agriculture and Forestry, Springer-Verlag, Berlin. 17:53-70

Bailian Li, Wyckoff GW (1994) Breeding strategies for Larix decidua, L. Leptolepis and their hybrids in the United States. For Genet 1:65-72

Beardmore T, Charest PJ (1995) Black spruce somatic embryo germination and desiccation tolerance. I. Effects of abscisic acid, cold, and heat treatments on the germinability of mature black spruce somatic embryos. Can J For Res 25:1763-1772

Bonga JM, Pond SE (1991) Adventitious shoot formation in cultures of 30-year-old Larix decidua, L. leptolepis, L. eurolepis, and L. larcina trees. Plant Cell Tiss Org Cult 26:45-51

Diner AM, Strickler A, Karnosky DF (1986) Initiation, elongation, and remultiplication of Larix decidua micropropagules. New Zealand J For Sci 16:306-318

Einspahr DW, McDonough TJ, Joachimedes T (1983) Kraft pulping characteristics of European, Japanese, and European $\times$ Japanese larch hybrids. Tappi 66:72-76

Gowere ST, Richards JH (1990) Larches: deciduous conifers in an evergreen world. Biosci 40:818-826

Gupta PK, Durzan DL (1989) Plantlet regeneration via somatic embryogenesis from subcultured callus of mature embryos of Picea abies (Norway spruce). In Vitro Cell Develop Biol-Plant

\section{2:685-688}

Hatton JV (1986) Chemical and pulping properties. In: Larch Workshop Proceedings. Fredericton, NB, October 14, New Brunswick Forest Research Advisor Committee. pp.17-305

Klimaszewska K (1989) Plantlet developmental from immature zygotic embryos of hybrid larch through somatic embryogenesis. Plant Sci 63:95-103

Lelu MA, Bastien C, Klimaszewska K, Ward C, Charest PJ (1994a) An improved method for somatic plantlet production in hybrid larch (Larix $\times$ leptoeuropaea): Part 1. Somatic embryo maturation Plant Cell Tiss Org Cult 36:107-115

Lelu MA, Klimaszewska K, Charest PJ (1994b) Somatic embryogenesis from immature and mature zygotic embryos and from cotyledons and needles of somatic plantlets of Larix. Can J For Res 24:100-106

Liao YK, Amerson H (1995) Slash pine (Pinus elliottii Engelm) somatic embryogenesis I. Initiation of embryogenic cultures from immature zygotic embryos. New For 10:145-163

Litvay JD, Verma DC, Johnson MA (1985) Influence of a loblolly pine (Pinus taeda L.) culture medium and its components on growth and somatic embryogenesis of the wild carrot (Darcus carota L.) Plant Cell Rep 4:325-328

Lu CV, Thorpe TA (1986) Somatic embryogenesis and plantlet regeneration in cultured immature embryos of Picea glauca. $\mathrm{J}$ Plant Physiol 128:297-302

Nagmani R, Bonga JM (1985) Embryogenesis in subcultured callus of Larix decidua. Can J For Res 15:1088-1091

Quoirin M, Lepoivre P (1977) Étude de milleux adates aux cultures in vitro de Prunus. Acta Hortic 78:439-432

Schenk RV, Hildebrandt AC (1972) Medium and techniques for induction and growth of monocotyledonous plant cell cultures. Can J Bot 50:199-204

Thompson RG, von Aderkas P (1992) Somatic embryogenesis and plant regeneration from immature embryos of western larch. Plant Cell Rep 11:379-385

Verhagen SA, Wana SR(1989) Norway spruce somatic embryogenesis: high-frequency initiation from light-cultured mature embryos. Plant Cell Tiss Org Cult 16:103-111

von Aderkas P, Bonga JM (1987) Promotion of embryogenesis in cultured megagametophytes of Larix decidua. Can J For Res 17:1293-1296

von Aderkas P, Bonga JM (1988) Formation of haploid embroids of Larix deciuda : early embryogenesis. Am J Bot 75:690-700.

von Aderkas P, Klimaszewska K, Bonga JM (1990) Diploid and haploid embryogenesis in Larch leptolepis, L. decidua, and their reciprocal hybrids. Can J For Res 20:9-14

von Arnold S, Hakman I (1986) Effects of sucrose on initiation of embryogenic callus cultures from mature zygotic embryos of Picea abies (L) Karst (Norway spruce). J Plant Physiol 122:261-265 